\title{
The research and practice of computer professional innovation personnel training mode
}

\author{
Shen Wei ${ }^{1, a^{*}}$, An Baiyi ${ }^{2, b}$ \\ ${ }^{1}$ College of Computer Science and Technology, Beihua University, Jilin, China \\ ${ }^{2}$ College of Horticulture, Jilin Agricultural University, Jilin, China \\ aabyswabysw@163.com, bswabyswaby@163.com
}

\section{Keywords: Model, Cultivation, Innovation, Training scheme}

\begin{abstract}
Computer as an emerging discipline, is rapidly developing and expanding its application field, change in the field of computer to computer talented person put forward higher requirements, so the computer major in colleges and universities advocate innovation entrepreneurship education is in line with market demand, based on the research on the basis of the theory of creative education in colleges and universities at home and abroad, the computer professional students' innovative entrepreneurial education model in colleges and universities for further exploration.
\end{abstract}

\section{Introduction}

Developed countries to the education mode of the early start and in constant exploration research.Institutions through the United States[1], China, Hong Kong and the mainland some Computer professional undergraduate course teaching system of the status quo analysis, you can see that the school teaching system[2], there are big differences between them in their respective characteristics, on the basis of are gradually absorbed the IEEE/ACM "Computer Curricula 2004" (hereinafter referred to as CC2004) some of the concept of curriculum reform[3].

1)At the Massachusetts institute of technology with electronic electrical professional deep fusion (its name is electrical engineering and computer science department[4], computer professionals with strong "hardcore" color, clearly emphasize the integration of computer and electronic, its hardware courses are very heavy, and the experimental course of hardware and software are very solid;

2)At the Chinese university of Hong Kong on company internship system adopted a flexible and effective way[5];

3)At tsinghua university in order to strengthen the basis of the mathematical aspects, put the part of students directly in physical training, and set up the theory of computer direction experimental classes[6];

4)Beijing university will training goal orientation in the field of leading talents with international vision, specifically is to cultivate research talents with creative ability[7], capable of integrated engineering talents and management talents with ability of organization.

This topic research will comprehensively promote professional teaching content and course system of research and reform, actively explore innovative personnel training mode[8], actively advocates the innovation of education concept, improving the cultivation of students' innovative consciousness and innovative ability.Accumulated valuable experience to explore education reform, the school education teaching reform, promoting and demonstration effect.

Through the construction of innovative talent training mode, set up take the student as the education teaching idea[9], respect students' personality development.Culture is the total of basic knowledge of electronic and information profession, systematically master computer science theory, the basic knowledge of computer hardware and software system, in a certain field has the specialty, has innovation consciousness and innovation ability of the computer professional senior specialized talents.

According to the current situation of computer science and technology professional development and the social demand, take the quality as the fundamental, with measures to guarantee, powered by demand, by strengthening discipline construction and the construction of teachers team construction 
and teaching conditions, promote the improvement of teaching quality, to ensure "strengthening foundation, outstanding ability, pay attention to quality, innovation" training mode[10].

\section{The meaning of computer professional personnel training mode innovative research}

Local undergraduate colleges and universities of applied talents training mode of innovative research is the need of education teaching reform

Computer science a prominent problem is the student actual work ability is poor, from theory to practice is a major cause of lead to this situation.Teachers as well as students from theory to practice[11], from theory to practice., through the industry-university-institute cooperation can promote the course system, teaching content and teaching method reform means constantly updated, for scientific research is to promote and stimulate the development of teaching, promote the teachers' teaching thoughts and teaching ideas of updates, solve theory divorced from reality and so on some important problems in the education teaching reform, improve the education the teaching quality.

Local undergraduate colleges and universities of applied talents training mode of innovative research is the need of local economic development

As local undergraduate colleges and universities, college is human resources reserve base of local economic development.To provide high quality applied talents for local economic development, to provide a line for production and management needs of talents, fill the blank of the local talent shortage and imbalance in the structure of talent, is the school's social responsibility and historical mission[12], and the cultivation of applied talents to satisfy the social demand for talents.As a new economic growth in local area of the power supply, can promote the development of local regional economy; The local regional economic prosperity, will accelerate the development of local colleges and universities.

Local undergraduate colleges and universities of applied talents training mode of innovative research is the need of sustainable development of the school

Local undergraduate colleges and universities of undergraduate course education history is shorter[13], inexperienced undergraduate education, undergraduate education and teaching of each work is still in the initial stage of development, in the face of increased competition in the education teaching resources between colleges and universities, students and talent training quality of competition, must through exploring the applied talents training mode, gradually formed its own characteristics.

\section{The content of the computer professional personnel training mode innovative research}

\section{To adjust the curriculum, build up reasonable curriculum system}

1) Clear training objectives, training scheme is determined

Four years training period is divided into two segments $(2+2$ mode $)$ : pay attention to broaden the foundation course, two years before in the practice of general education and the necessary training; To grade 3 according to the demands of students, implement the training mode of professional education.

2) To set up curriculum system to the principle of dynamic and development

Fast development of computer technology and professional curriculum design (including compulsory courses, elective courses and practice courses) to keep up with the development of new technology, to constantly revise training plan and content.

3) Into the "diversity" of innovation elements, carefully set up the course system

Appropriate increase in the volume one, grade two courses, make students keep a high school stage study strenuously, basically complete theory teaching in three years, four grade the first semester began to engineering practice and graduation design (paper), at the same time pay attention to their aptitude, set the multimodal training scheme.

4) In order to improve the students application ability as the starting point to design the curriculum system 
Colleges and universities should actively strive for local resources, vigorously improve the school teaching facilities and the experimental conditions;To strengthen cooperation with area related enterprises, and actively building off-campus practice base.Should attach great importance to the teaching and the arrangement of the content of experiment, and train the practical activities into the overall scheme, in order to improve the students' enthusiasm to participate in practice lesson, to cultivate students' innovation consciousness and practice ability.

\section{Improve the teaching methods, strengthen the construction of teaching staff}

1) The integration of production, study and develop

Undergraduate schools, scientific research units, factories and enterprises series, training mode of establishing university - enterprise research consortium, development and application research institute, the cooperative research centre, university-enterprise cooperation training base, the construction of science and technology park or high technology industry area, etc.

2) The tutorial system to improve the talent training scheme

Students can determine the professional direction of according to oneself choose their instructor (work is mainly responsible for student's study, participants are responsible for the daily management of students), rather than choose when doing graduation thesis papers instructor.The tutor system can make students according to their interests of learning team, improve their ability to study independently.

3) The innovative talent cultivation

Selection of junior undergraduate top students into innovative experimental classes, allowing the experimental classes of students in the finished ahead of specialized courses under the guidance of tutor, or to choose their interested in subject direction part and complete the course, the implementation of personal cultivation.

\section{To develop students' comprehensive quality based on science and technology activities}

1) To build three platforms three big system.

Strive to build "classroom teaching, practice teaching, the development of quality" three big system, consolidate the "general education, discipline foundation, practice teaching" three big platform;Change traditional the excessive pursuit of systematic, integrity, discipline theory knowledge, theory, practice, neglecting the students' innovative consciousness and practice ability, strive to build "based on quality and ability as the standard" mode of curriculum structure, integrated optimization of teaching content and system.

2) Build perfect experiment system and the environment, good platform for students to improve innovation ability

After construction, we build the perfect experiment system, there are abundant, equipment advanced, full-featured digital circuits, analog circuits and microcomputer system composition and system structure and application, computer, communication and network, the embedded system, digital media, such as seven professional laboratory, three joint laboratory of new technology and a comprehensive application and innovation laboratory.These LABS are fully open to the students' practice and the extracurricular activities of science and technology provides a good platform.

3) Encourage academic competition, for students' innovation consciousness to improve rich atmosphere

Actively encourage students to participate in business activities to improve the students' practical ability, can through the community college students form a computer science and technology association, as a link to a community organization students to participate in extra-curricular science and technology culture activity.

\section{Conclusion}

In this paper, based on innovative talents training mode of computer professional teaching reform research and practice are discussed in this paper, analyzes the present situation of computer science, put forward the reform target, has been clear about the specific content of the reform, the implementation plan and specific implementation plan, and expounds the features of this subject well. 


\section{Acknowledgement}

The authors wish to thank the Education Department of Jilin Province [2015](127th) and [2015](182nd),Jilin science and Technology Bureau(201467006), Science and Technology Department of Jilin Province (20150204045NY), Jilin Province Education Science Planning Project (GH14126)、(GH14127)under which the present work was possible.

\section{References}

[1] Anders Lundstrom, Lois Stevenson. Entrepreneurship Policy: Theory and Practice[M]. Springer, 2010.

[2] Nabi G, et al. From student to entrepreneur: Towards a model of graduate entrepreneurial career-making[J].Journal of Education and Work, 2010,23(5):389-411.

[3] Nabi G, et al. From student to entrepreneur: Towards a model of graduate entrepreneurial career-making[J].Journal of Education and Work, 2010,23(5):389-411.

[4] Youtie J , Shapira P. Building an innovation hub: a case study of the transformation of university roles in regional technological and economic development[J]. Research Policy, 2008, 37(8): 1188-1204.

[5] Wallmark J T, McQueen D H, Sedig K Q. Measurement of output from university research, a case study[J]. Engineering Management, IEEE Transactions, 2008, 3:175-180.

[6] Emest L Boyer. Schlarship Reconsidered: Priorities of the Professoriate. Princeton: The Camegie Foundation for the Advancement of Teaching, 1990.

[7] Fini R, Grimaldi R, Santoni S, et al. Complements or substitutes? The role of universities and local context in supporting the creation of academic spin-offs[J].Research Policy, 2011, 40(8): 1113-1127.

[8] Information on http://www.people.com.cn/GB/32306/33232/14743200.html

[9] Information on http://www.ox.ac.uk/about/oxford-people/famous-oxonians

[10] Anders Lundstrom, Lois Stevenson. Entrepreneurship Policy: Theory and Practice[M]. Springer,2010.

[11] Lucia Naldi,Mattisa Nordqvist.Entrepreneurial Orientation,Risk Taking,and performance in Family Firms[J].Journal of the family firm institute,2007(1):33-47.

[12] Anders Lundstrom,Lois Stevenson. Entrepreneurship Policy:Theory and practice[M].New Mexico,Springer,2005.

[13] Geenhuizen M V, Soetanto D P. Academic spin-offs at different ages: A case study in search of key obstacles to growth[J]. Technovation, 2009, 29(10):671-681. 